\title{
Kan Jorden miste balancen? - Palceomagnetikere leder efter svaret
}

Af Peter Riisager, Carlsbergstipendiat, Geologisk Museum, Københavns Universitet og GeoBiosphere Science Centre, Lund

Det er svært at forestille sig, at en hel planet kan miste balancen. Det er ikke desto mindre det, der muligvis er sket tidligere i Jordens geologiske historie. Det drejer sig om det mærkelige fænomen "polvandring”, hvor hele Jorden tipper i forhold til rotationsaksen. I disse år forskes der intenst i polvandring og specielt den mulige indflydelse, som polvandring har haft på Jordens klima og livets udvikling.

Igennem de sidste hundrede år er polvandring blevet målt direkte, først med astronomiske observationer og nu med avancerede satellitteknikker som for eksempel Global Positioning System. Derfor ved vi, at Jorden i disse år udsættes for en polvandring med en hastighed på cirka $10 \mathrm{~cm} / \mathrm{år}$ (se figuren ovenfor). Målingen af polvandring er uafhængig af pladetektonik og kontinentaldrift. Hele Jorden vipper.

\section{Igangværende polvandring}

Jordens igangværende polvandring, mener man, skyldes sidste istid, der medførte en ændring af Jordens massebalance. Dels bandt isen en masse vand og medførte en global havniveauesænkning på cirka 100 meter. Dels skubbede de kilometertykke iskapper Jordens overflade ned. I dag er iskapperne smeltet, og Jordens overflade stiger nogle steder et par centimeter om året. Selvom istidens masseomfordeling synes meget lille i forhold til Jordens samlede masse, så er det altså nok til at skabe polvandring.

\section{Inertimoment og polvandring}

For at forstå polvandring skal vi en tur omkring klassisk mekanik og begrebet inertimoment, der beskriver trægheden i roterende legemer. Jo større inertimoment, et legeme har, desto større drejningsmoment skal der til for at accelerere eller decelerere dets rotation. Inertimomentet afhænger både af et legemes masse og dets massefordeling i forhold til rotationsaksen. Man kan udregne intertimomentet (I) for en punktmasse med masse (m) og vinkelret afstand fra rotation-

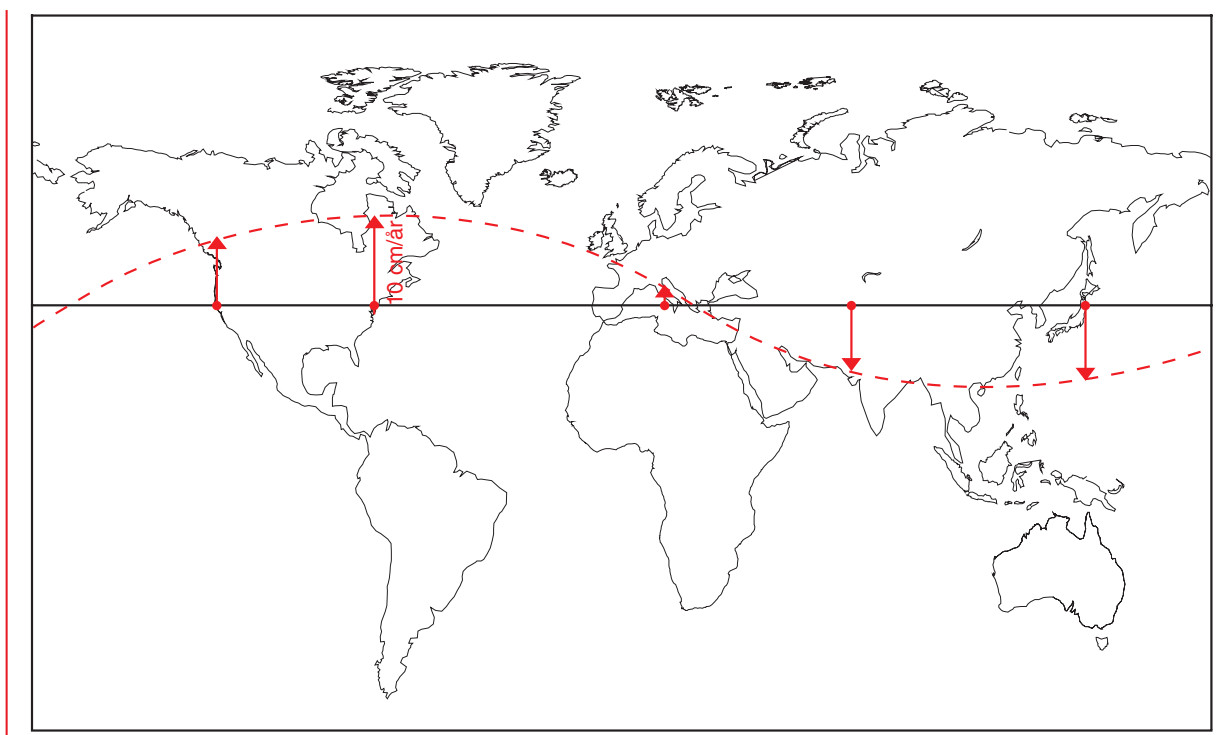

Direkte observation af polvandring fra fem “International Latitude Service” målestationer (Mizusawa, Carloforte, Gaithersburg, Ukiah, og Kitab). Pilene viser stationernes bevagelse imod eller vak fra den geografiske nordpol over perioden fra 1900 til 1964. (Grafik: Forfatteren)

saksen (r) ud fra den simple formel: $\mathrm{I}=\mathrm{mr}^{2}$. Da alle legemer kan beskrives ved en samling af punktmasser, kan man ud fra denne formel udregne inertimoment for et givent legeme. Jordens inertimoment er udregnet til lidt over $8 \times 10^{37} \mathrm{~kg} \mathrm{~m}^{2}$, og fordi Jorden ikke er helt rund, varierer inertimomentet lidt afhængigt af omkring, hvilken rotationsakse man udregner inertimomentet. Jordens rotation og den medfølgende centrifugalkraft gør nemlig at Jordens ækvatoriale radius i gennemsnit er $21 \mathrm{~km}$ mere end ved polerne. Man kan sige, at Jorden buler ud ved ækvator.

På grund af den ækvatoriale bule er aksen med det største inertimoment sammenfaldende med Jordens nuværende rotationsakse. Man kan teoretisk vise, at Jorden altid vil fortsætte med at rotere om aksen med det største inertimoment. Den ækvatoriale bule er altså med til at stabilisere Jorden og modvirke polvandring. Polvandring vil kun finde sted, hvis Jordens massefordeling ændres så meget, at aksen for det maksimale inertimoment ændres. Via konvektion i kappen kan der muligvis ske masseomfordelinger tilstrækkeligt store til at forårsage polvandring.

\section{Polvandring på en tænkt planet}

Man kan illustrere baggrunden for polvandring ved et simpelt og tænkt eksempel. En lille plastisk deformerbar klode, der rote- rer i rummet. På klodens ækvator er en stor bille (se figuren nedenfor). Hvis billen langsomt begynder at kravle væk fra ækvator

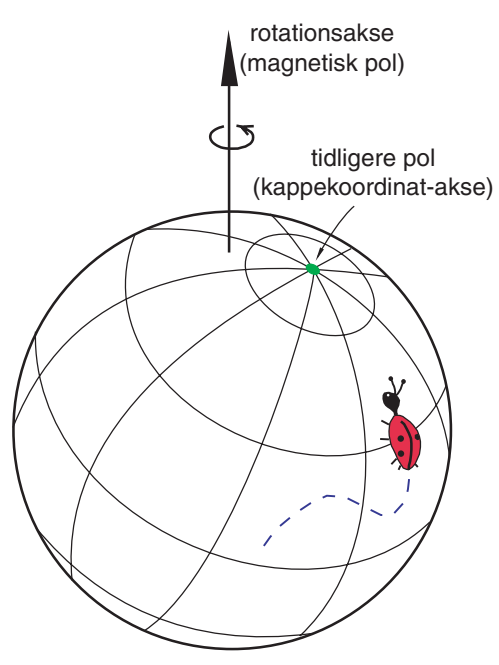

Eksempel der forklarer baggrunden for polvandring. En bille kravler over en plastisk deformerbar klode, der roterer i rummet. Billens bevcegelse reprcesenterer en masseomfordeling tilstrckkelig stor til at cendre klodens inertimoment og forårsage polvandring. Når billen kravler, vil kloden tippe over imod billen, således at den altid vil befinde sig på klodens cekvator langst mulig veek fra rotationsaksen. (Grafik: Forfatteren) 
(mod nord eller syd), så vil den faktisk aldrig forlade ækvator. Kloden vil i stedet vælte over imod billen, således at den ekstra masse, som billen repræsenterer, altid befinder sig længst muligt væk fra rotationsaksen. Med andre ord vil billen være årsag til, at kloden mister balancen og udsættes for polvandring. Saint Exupérys lille Prins skulle i teorien også have oplevet polvandring, når han vandrede rundt på sin lille planet.

\section{Polvandring på Jorden}

På Jorden findes der heldigvis ikke biller så store, at de kan forårsage polvandring. Til gengæld sker der hele tiden masseomfordelinger når varme, der produceres i Jordens indre, transporteres til overfladen via konvektion (figuren ovenfor). Desværre ved vi kun meget lidt om kappens nuværende fordeling af masse og endnu mindre om tidligere tiders fordeling. Derfor er det umiddelbart svært at vide, om masseomfordelinger i kappen er store nok til at skabe polvandring. Heldigvis er der en helt anden indgangsvinkel til at undersøge fænomenet polvandring. Via palæomagnetiske undersøgelser er det nemlig muligt at bestemme positionen af rotationsaksen tilbage i Jordens geologiske historie. Palæomagnetiske undersøgelser muliggør derfor en kvalificeret diskussion om eksistensen af polvandring på Jorden.

\section{Palæomagnetisk bestemmelse}

Jordens magnetfelt dannes i den ydre kerne, der strækker sig fra 2.900 til 5.100 km’s dybde og hovedsageligt består af smeltet jern (90\%) og lettere elementer (10\%). Jordens rotation spiller en afgørende rolle for magnetfeltet og gør, at feltet er rettet langs Jordens rotationsakse, således at de magnetiske poler ligger tæt på de geografiske poler. Midlet over et par tusinde år er de magnetiske poler endda sammenfaldende
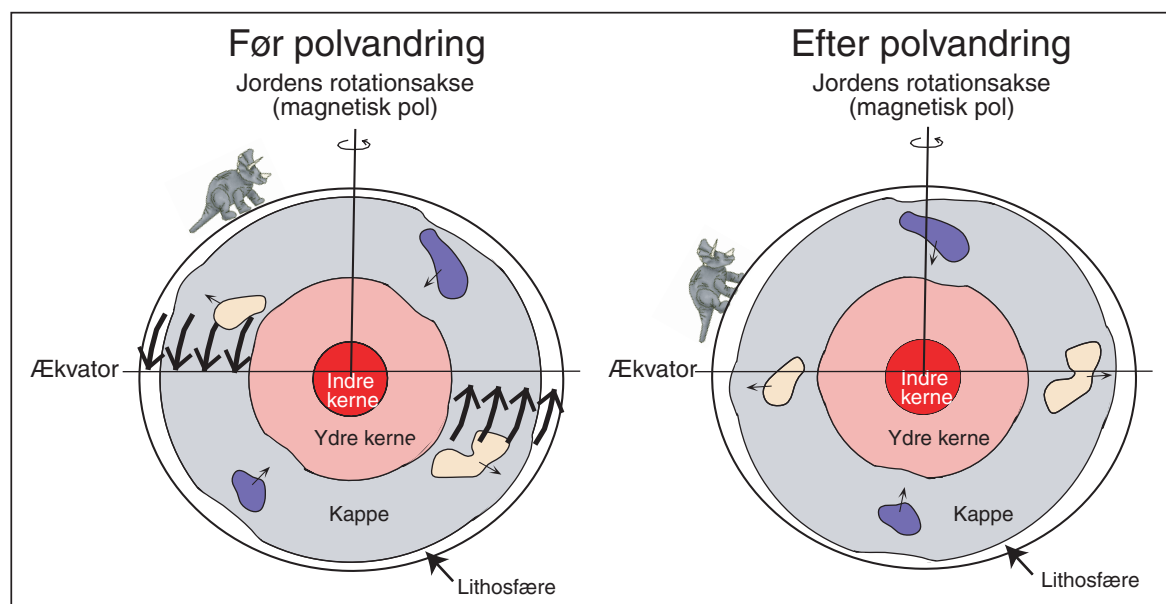

Vertikale strømninger i Jordens kappe forårsaget af konvektion kan forskubbe kappens øvre og nedre grcenser. Udbulninger reprcesenterer en ekstra masse, der kan cendre Jordens inertimoment og forårsage polvandring. (Grafik: Forfatteren) med de geografiske poler (figuren nedenfor). Ved at bestemme den tidligere position af Jordens tidsmidlede magnetfelt kan man derfor bestemme den tidligere position af Jordens geografiske pol (og dermed rotationsaksen). Ved at bestemme Jordens tidligere rotationsakse kan man i princippet undersøge, om Jorden er tippet i forhold til rotationsaksen, og polvandring har fundet sted (figuren ovenfor). Et afgørende spørgs- mål er, hvordan og hvor præcist man kan bestemme Jordens tidligere magnetfelt? Faktisk er en hel videnskab, kaldet "palæomagnetisme”, dedikeret til dette spørgsmål.

Palæomagnetisme er baseret på det faktum, at stort set alle bjergarter indeholder magnetiske korn, der ved bjergartens dannelsestidspunkt optager og gemmer en magnetisering bestemt af det omgivende magnetfelt. Ved at studere magnetiseringen

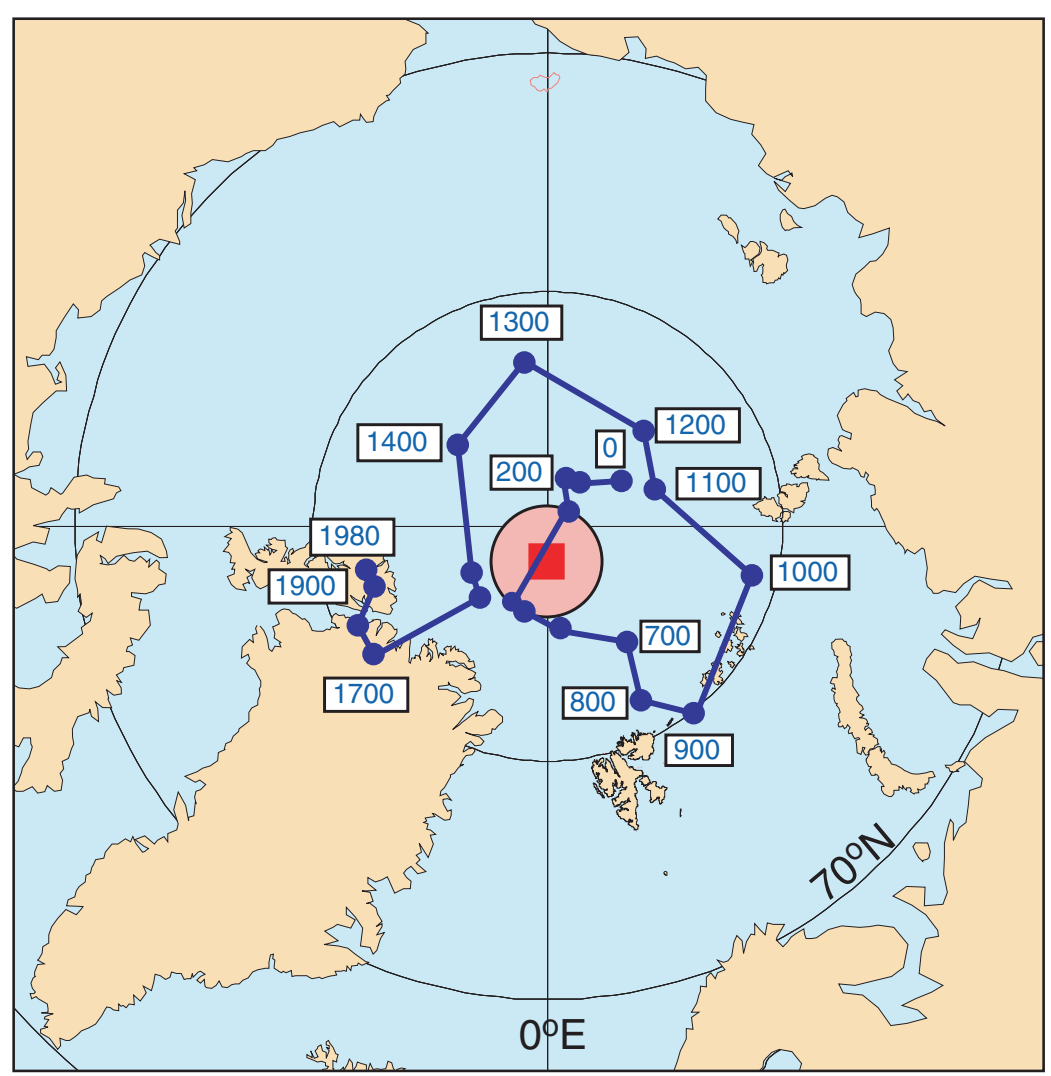

Jordens magnetiske nordpol for de sidste 2.000 år. Den magnetiske pol er sjceldent helt sammenfaldende med den geografiske pol. Men ser man på den tidsmidlede magnetiske pol for de sidste 2.000 år (rød firkant), er den faktisk statistisk sammenfaldende med den geografiske pol. Ved at bestemme det tidsmidlede magnetfelt for tidligere geologiske perioder kan man derfor bestemme positionen af Jordens tidligere geografiske pol (dvs. den tidligere position af rotationsaksen) og dermed undersøge, om polvandring har fundet sted. (Grafik: Forfatteren) 
af geologiske prøver kan man derfor bestemme Jordens tidligere magnetfelt. I virkeligheden er det dog ofte svært, fordi forvitring, varme og kemiske omdannelser kan slette den oprindelige magnetisering. Selvom palæomagnetikere bruger detaljerede laboratorieteknikker til at isolere den oprindelige magnetisering, er det ofte vanskeligt at sige med sikkerhed, om det er lykkedes eller ej. Palæomagnetiske usikkerheder er en af grundenetil, at polvandring stadig debatteres.

En anden vanskelighed ved at bestemme polvandring er kontinentaldrift. Det vil sige det faktum, at lithosfæreplader bevæger sig rundt på vores planet via pladetektoniske kræfter. Ved kontinentaldrift flyttes den palæomagnetiske optagelse væk fra sit oprindelige optagelsessted. Det er et problem, fordi bjergartens dannelsessted er en forudsætning for at bruge palæomagnetiske poler til bestemmelse af polvandring. Inden man kan bruge palæomagnetiske data til at bestemme polvandring, er det derfor nødvendigt at korrigere for kontinentaldrift. Heldigvis kan pladetektoniske bevægelser bestemmes uafhængigt af palæomagnetiske data ved hjælp af de såkaldte kappesøjler, der er kanaler fra jordens dybere lag, hvorigennem
Jordens lithosfare består af plader, der bevager sig i forhold til hinanden. På figuren bevceger de to pla$\operatorname{der}(A \circ g$ B) imod hinanden, og der dannes $i$ bjergkcede, hvor de støder sammen. Den pladetektoniske bevcegelse for plade A kan bestemmes via det kappesøjlespor, der dannes, når pladen bevager sig henover det $i$ kappen fikserede hotspot. (Grafik: Forfatteren)

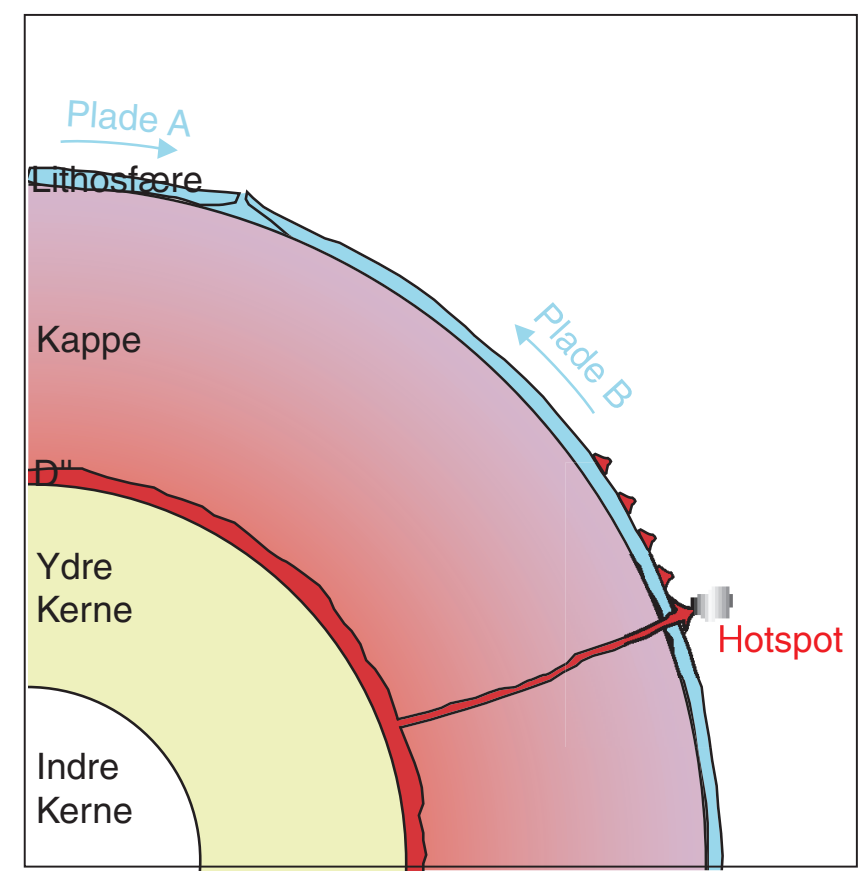

varmt materiale sendes op til overfladen.

Kappesøjlerne er fikserede i kappen, og når en lithosfæreplade bevæger sig henover

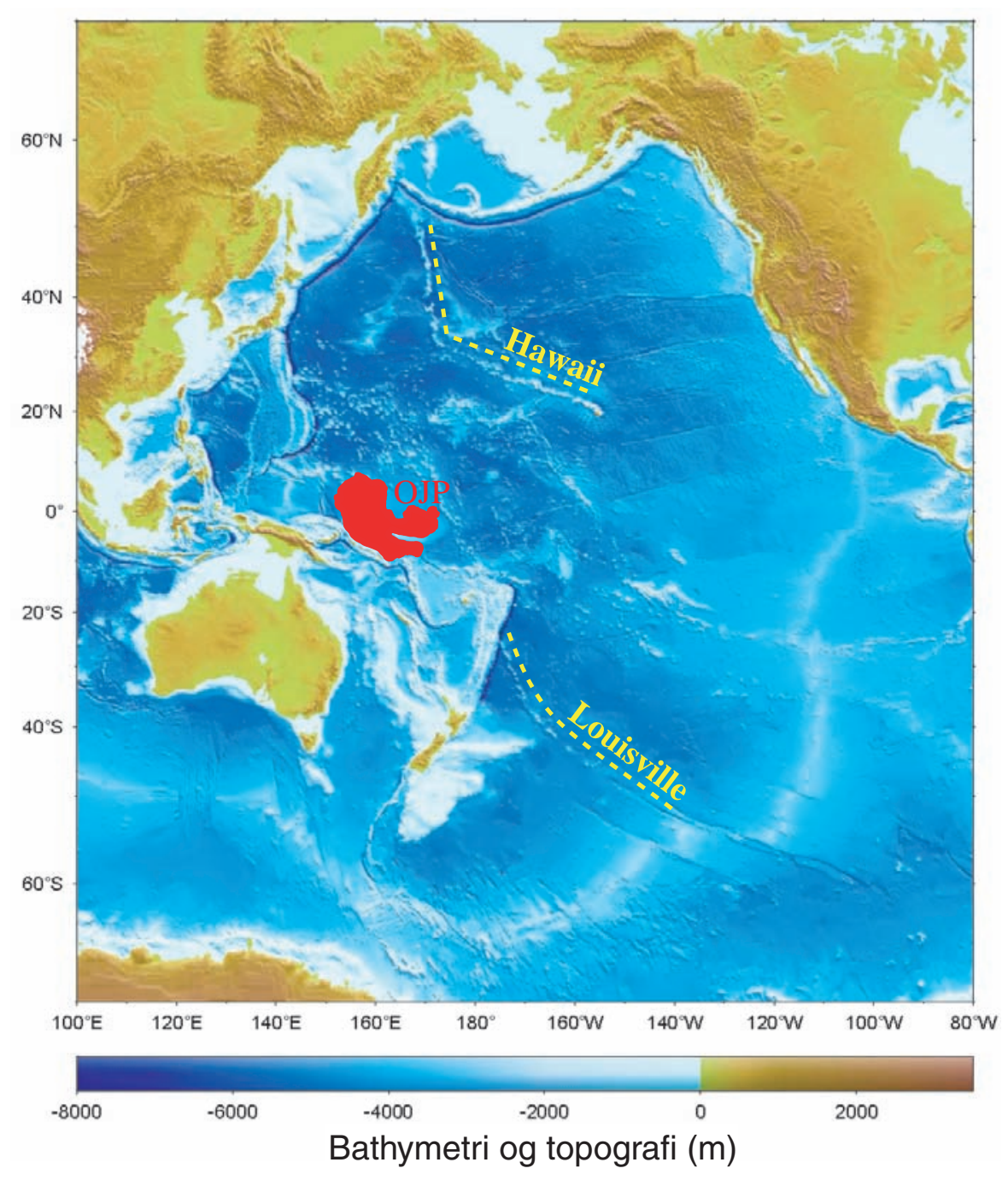

Undersøisk topografi for Stillehavspladen. Den undersøiske Hawai-Emperor økæede er dannet ved Stillehavspladen og har bevceget sig over det hotspot, der nu befinder sig under Hawaii. (Grafik: Forfatteren) kappesøjlerne, dannes der vulkanske spor (figuren øverst ovenfor). Det bedste eksempel på et sådant kappesøjlespor er HawaiiEmperor økæden, der er dannet ved, at Stillehavspladen har bevæget sig over den kappesøjle (hotspot), der nu befinder sig under Hawaii. Ved at bruge kappesøjlespor kan vi korrigere palæomagnetiske poler for pladetektonik og dermed direkte bestemme polvandring. I disse år arbejdes der intenst på bedre at definere polvandring og i denne forbindelse fokuseres der specielt på Stillehavspladen, fordi det er her, vi finder de bedst definerede økæder fra kappesøjler. Desværre er Stillehavspladen også specielt vanskelig, fordi indsamling af geologiske prøver kun kan ske ved kostbare og vanskelige oceanbundsboringer (se boksen på modstående side).

Baseret på eksisterende palæomagnetiske data er der ingen indikation på, at polvandring har fundet sted i løbet af de sidste 65 millioner år. Længere tilbage i vores planets geologiske historie har der til gengæld været korte perioder, hvor ekstremt hurtig polvandring tilsyneladende har fundet sted (figuren nederst side 8). Det interessante ved de hurtige polvandringer er, at de tilsyneladende falder sammen med ekstraordinære geologiske begivenheder. Der er derfor god grund til at antage, at polvandringer kan have forårsaget store omvæltninger for vor planet.

\section{Polvandring og klima}

Fundamentalt set er Jordens klima kontrolleret af balancen mellem den stråling, som Jorden modtager fra Solen, og den stråling, som Jorden selv udsender. Ca. 2/3 af Solens stråling absorberes af Jordens atmosfære og overflade. Jo mere af Solens stråling der absorberes, jo højere vil temperaturen blive. Havområder absorberer omkring 90 \% af Solens stråler, mens landområder absorberer 


\section{Videnskabelige boringer $\mathrm{i}$ oceanerne}

Mere end $70 \%$ af vores planet er dækket af oceaner. For at forstå Jordens fortid, nutid og fremtid er det derfor vigtigt at studere oceanerne og de geologiske aflejringer, der findes på deres bund. I denne forbindelse har geovidenskaberne fundet sammen i et internationalt samarbejde, hvor en bred vifte af lande, inklusiv Danmark, deles om de store omkostninger forbundet med at bore og optage borekerner fra oceanbunden. Igennem de sidste 40 år har videnskabsfolk boret over 2.900 huller, hentet mere end 300 kilometer borekerne og herigennem fået afgørende viden om vores planet. Det er via oceanboreprogrammet, at vi har haft mulighed for at studere den palæomagnetiske udvikling af Stillehavspladen, og skaffet afgørende data til at studere polvandring. At det er forbundet med store investeringer kan illustreres ved det nyeste boreskib, der har et "prisskilt" på 475 millioner US dollars og årlige omkostninger på 160 millioner US dollars.

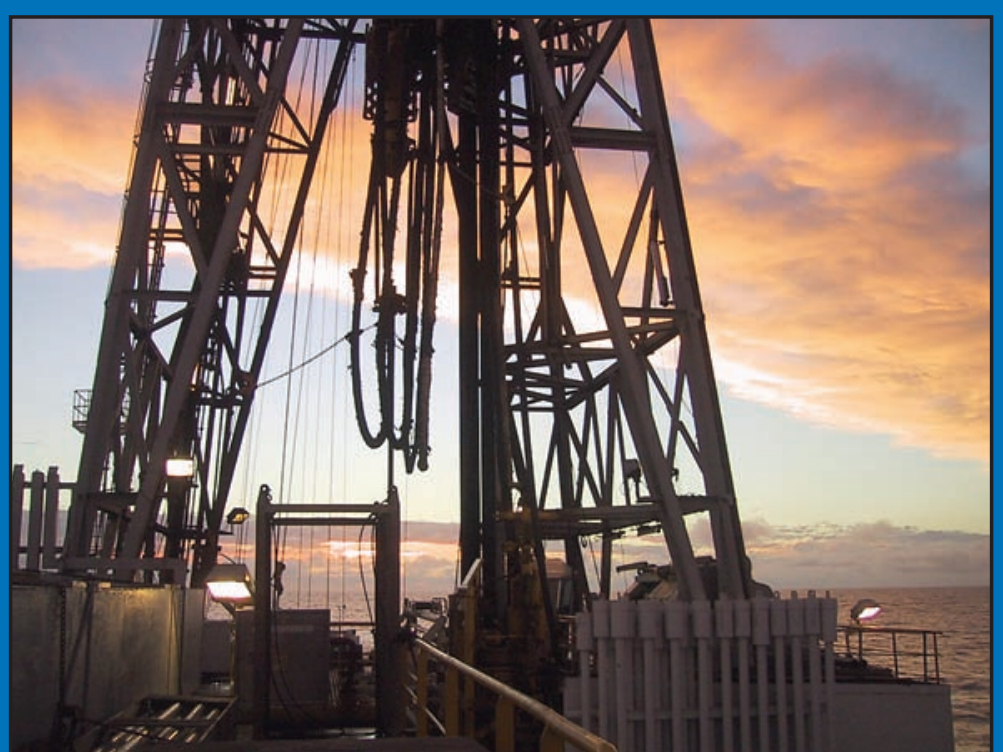

Boreskibet Joides Resolution fra det netop afsluttede Ocean Drilling Program. Skibet er udstyret med et palceomagnetisk laboratorium, så borekerner kan undersøges så snart de bringes til overfladen. (Foto: Xixi Zhao) en langt mindre del af strålingen. Ved polvandring skal den ækvatoriale bule flyttes, og det vil ifølge teoretiske modeller forårsage globale havniveaustigninger på op til 200 meter. Det vil oversvømme enorme områder af Jordens kontinenter, og Jorden vil som helhed absorbere mere stråling, hvilket vil medføre en global temperaturstigning. Desuden vil polvandring hurtigt omfordele Jordens kontinenter og dermed ændre globale havstrømninger, der igen spiller sammen med klimaet. Man kan bare se på, hvor stor indflydelse Golfstrømmen har på klimaet i Nordeuropa. Udover klimaændringer vil en havstigning på 200 meter naturligvis også være alvorlig for udvalgte kystnære økosystemer. For at sætte det i relief kan man sammenligne med worst-case-scenariet for klimainduceret havniveaustigning der er mindre end 1 meter frem til år 2100.

Med hensyn til polvandring og klima er det interessant at kigge på den geologiske periode Kridt, der strækker sig fra 145,5 til
65,5 millioner år siden. Kridttiden var en speciel tid i Jordens geologiske historie. Klimaet var varmere end $i$ andre perioder, temperaturforskellen over breddegraderne var mindre, og der var ingen eller kun meget små iskapper ved polerne. Havenes vandstand var desuden betydeligt højere, de dybe oceaner oplevede flere perioder med verdensomspændende iltsvind, og masseuddøen fandt sted oftere end i andre perioder. Det er endnu ikke forstået, hvordan alle disse fænomener hænger sammen. Det interessante er, at de to sidste gange, hvor Jorden tilsyneladende oplevede polvandring, var i Kridt. Første gang for 110-120 millioner år siden, hvor Jorden tippede 20 grader i løbet af 5-10 millioner år. Anden gang for 84 millioner år siden hvor endnu 20 grader polvandring fandt sted over 2 millioner år (figuren nederst på næste side). Man overvejer derfor, om polvandring kan have spillet en direkte rolle for det meget varme klima i Kridt.

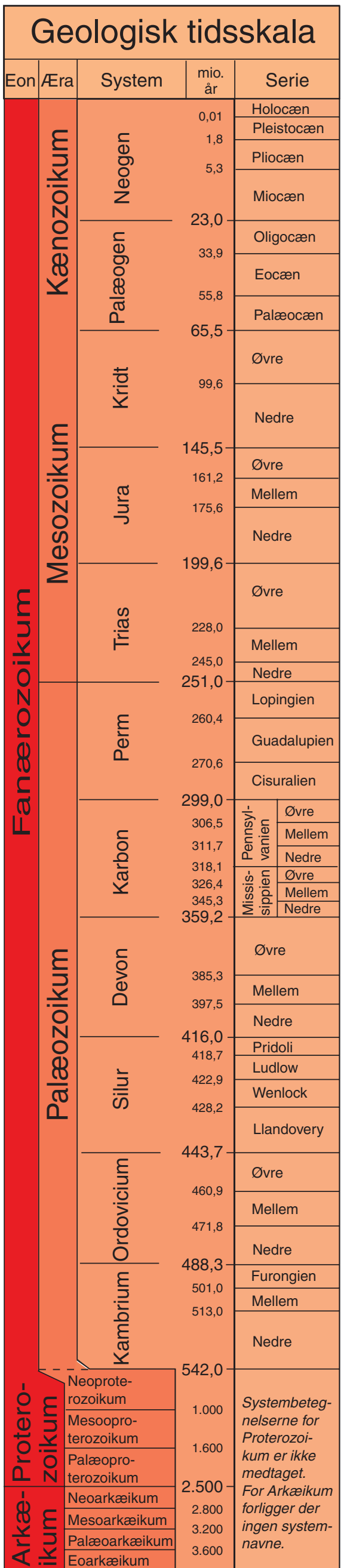


Polvandring og livets udvikling

Man kan ikke forestille sig en mere markant polvandring end de 90 grader, som man mener skulle have fundet sted for 550 millioner år siden. Polvandringen fandt ifølge palæomagnetiske data sted over en periode på 15 millioner år. I løbet af den tid flyttedes kontinenter, der lå ved nordpolen eller sydpolen, til ækvator, og to antipodale punkter ved ækvator blev de nye poler.

Det interessante er, at den 550 millioner år gamle polvandring falder sammen med skelsættende omvæltninger for vor planet. Jorden forlod således for 550 millioner år siden en global istid med tykke iskapper helt ned til ækvator. Udviklingen af flercellede organismer tog også pludselig fart, og alle de "kropsgrundplaner", der kan genfindes hos de fleste nulevende dyr, udvikledes over en relativt kort periode, kaldet den Kambriske Eksplosion af liv. Den globale optøning og den Kambriske Eksplosion af liv har længe været et mysterium. En polvandring på 90 grader er måske nøglen til disse mysterier. Ved 90 graders polvandring vil Jordens klima i hvert fald kunne ændres markant, og livet ville skulle tilpasse sig ændrede livsbetingelser via evolution.

\section{Hvorfor studere polvandring?}

Polvandring er en ekstraordinær teori, og man bør derfor forlange ekstraordinært gode beviser, førend teorien antages. Videnskabsfolk er ikke enige om de eksisterende beviser, og teorien må derfor anses som spændende, men endnu ikke fuldt godtgjort - juryen voterer stadig. Der er derfor god grund til for palæomagnetikere fortsat at jagte de bjergarter, der uden tvivl findes et eller andet sted, og som indeholder lige præcis det magnetiske signal, der kan fortælle os sandheden om polvandring. I øvrigt er pol-

vandring også en vigtig brik til at forstå andre planeter (se boksen til højre), og der er derfor god grund til at forske i polvandring på vores egen planet.

Hvis vi skal tro de eksisterende palæomagnetiske data, så har polvandring flyttet kontinenter på Jordens overflade med hastigheder på 1 meter om året, hvilket i geologisk sammenhæng er ekstremt hurtigt og meget hurtigere, end hvad vi kender fra pladetektonisk kontinentaldrift. På den anden side er hastigheder på 1 meter om året ikke nok til, at vi eller nærmest kommende generationer behøver at frygte ændrede livsbetingelser som følge af polvandring. Det er dog værd at bemærke, at Jordens nuværende inertimoment kun er ganske lidt højere langs rotationsaksen. Det er således muligt, at vi er på vej mod en ny omgang polvandring, og at Jordens geografi, klima og liv vil være totalt omvæltet om 10 millioner år. Vi må vente og se.

\section{Litteratur:}

Goldreich, P. \& Tomre A., Some remarks on Polar Wandering, Journal of Geophysical Research, 74: 2555-2567, 1969.

\section{Polvandring på andre planeter}

Hvis polvandring har fundet sted på Jorden, er der naturligvis god grund til at spekulere i, om polvandring også har fundet sted på andre planeter. Er det fx et tilfælde, at den vulkanske Tharsis-provins befinder sig på Mars ækvator? Eller skyldes det polvandring? Tharsis-provinsen, der strækker sig over 4.000 km og når en højde på op til 25 km, repræsenterer således den største positive tyngdefeltsanomali, der kendes fra nogen planet. Hvis Tharsis ikke oprindeligt dannedes ved ækvator, er det meget tænkeligt, at denne kæmpe masseanomali kan have ændret Mars’ inertimoment tilstrækkeligt til at forårsage polvandring.

Selvom der endnu ikke eksisterer egentlige palæomagnetiske undersøgelser fra Mars, eksisterer der indirekete magnetiske data fra den amerikanske satellit Mars Global Surveyor, som siden 1999 har kredset 400 km over Mars' overflade og blandt andet har målt planetens magnetfelt. Modellering af magnetiske data fra Mars Global Surveyor er faktisk i overensstemmelse med et palæomagnetfelt, der bedst forklares ved polvandring. Baseret på masseanomalier ved ækvator antages det, at polvandring også har fundet sted på vor egen måne, planeten Pluto, Jupiters måne Io, og Neptuns måne Triton.

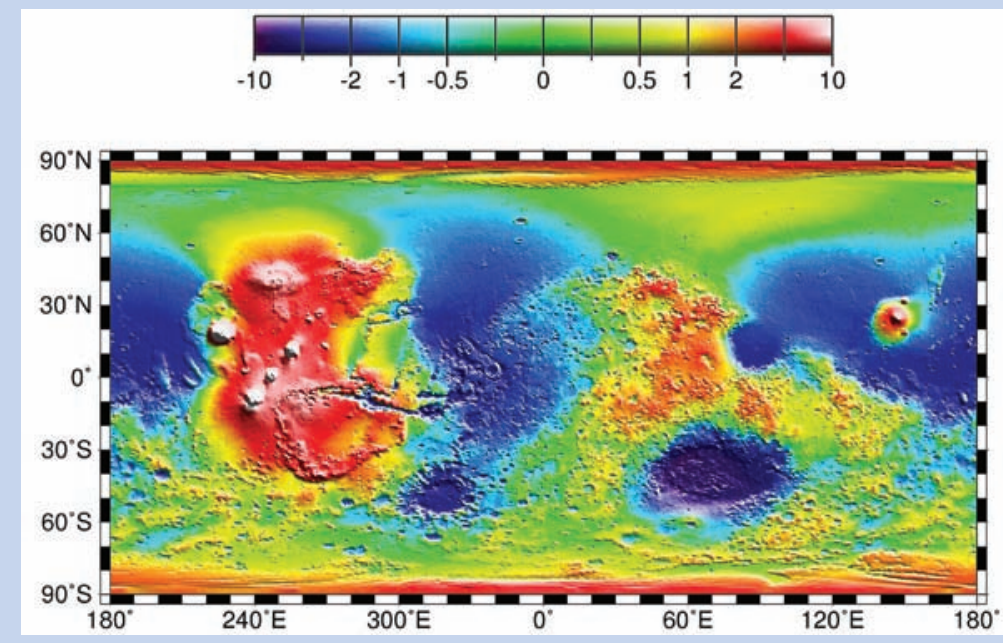

Den globale topografi på Mars. Den vulkanske Tharsis-provins er placeret på cekvator mellem 220 og $300^{\circ}$ Øst, hvor den strckker sig over 4.000 kilometer og nåren højde på op til 25 kilometer. Tharsis reprcesenterer den største positive tyngdefeltsanomali, der kendes fra nogen planet $i$ vort solsystem. Man mener, at Tharsismasseanomalien har forårsaget polvandring (sammenlign med billen på figuren på første side). (Grafik: Goddard Space Flight Center)

Kirschvink, J.L., Ripperdan, R.L., Evans, D.A., Evidence for a large-scale reorganization of early Cambrian continental masses by inertial interchange true polar wander, Science 277, 541-545, 1997. Riisager, P., Hall, S., Antretter, M. \& Zhao, X., Paleomagnetic Paleolatitude of Early Cretaceous Ontong Java Plateau
Basalts: Implications for Pacific

Apparent and True Polar Wander, Earth and Planetary Science Letters, 208 (3-4): 235-252, 2003

På hjemmesiden http://www.priisager.dk findes mere information om palceomagnetisme og polvandring

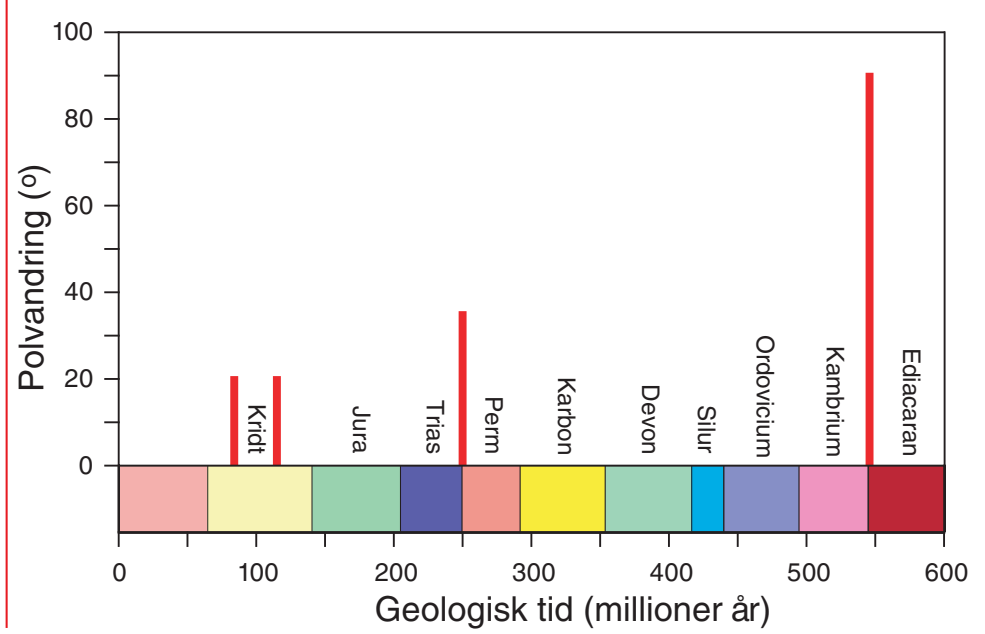

Palcomagnetiske data indikerer at fire hurtige polvandringsbegivenheder på mellem $20^{\circ}$ og $90^{\circ}$ har fundet sted inden for de sidste 600 millioner år. (Grafik: Forfatteren) 